PERSPECTIVA TEOLÓGICA ADERE A UMA LICENÇA CREATIVE COMMONS ATRIBUIÇÃO 4.0 INTERNACIONAL - (CC BY 4.0 )

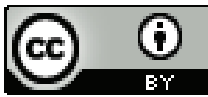

DOI: $10.20911 / 21768757 v 53 n 1 p 99 / 2021$

\title{
O PRIMADO DO AMOR NA AMORIS LAETITIA: APROXIMAÇÕES À TEOLOGIA DE DUNS SCOTUS *
}

\author{
The primacy of love in Amoris Laetitia: Approximations to Duns Scotus' Theology
}

Juliano Ribeiro Almeida **

RESUMO: Este artigo analisa particularmente a exortação apostólica pós-sinodal Amoris Laetitia, situando-a na mesma linha que outros textos promulgados pelo Papa Francisco, que priorizam a caridade em relação à verdade. Tal preferência aproxima o magistério deste pontificado da tradição filosófica e teológica chamada Escola Franciscana, especialmente na pessoa de João Duns Scotus, considerado um pensador à altura de Tomás de Aquino. O pensamento escotista, devido às suas importantes diferenças, representa uma alternativa em relação ao tomista. Em Amoris Laetitia, o Papa Francisco apresenta continuidade doutrinal com o magistério papal anterior, mas inova ao ressaltar mais o amor conjugal do que os aspectos canônicos do sacramento do matrimônio, o que abre espaço para novas práticas de pastoral familiar.

PALAVRAS-CHAVE: Amoris Laetitia. Papa Francisco. Duns Scotus. Amor conjugal.

ABSTRACT: This paper analyses the post-synodal apostolic exhortation Amoris Laetitia, in the same line with other texts promulgated by Pope Francis, that prioritize charity over truth. Such a preference brings this papal magisterium closer to the philosophical and theological tradition called the Franciscan School, espe-

\footnotetext{
* O artigo contém uma seção da tese doutoral de Juliano Ribeiro Almeida intitulada, Univocidade e diferença: a contribuição de Duns Scotus para uma Teologia Decolonial, defendida e aprovada junto à Faculdade Jesuíta de Filosofia e Teologia (FAJE) em 08 de maio de 2020 e orientada pelo Prof. Dr. Sinivaldo Silva Tavares com o apoio da FAPEMIG. A tese está disponível em: <https://www.faculdadejesuita.edu.br/teses-teologia-227/univocidade-e-diferenca-a-contribuicao-de-duns-scotus-para-uma-teologia-decolonial-11022021-155835>.

** Instituto Interdiocesano de Filosofia e Teologia, Vitória, Espírito Santo, Brasil.
} 
cially represented by John Duns Scotus, a thinker considered on par with Thomas Aquinas. Due to its particularities, Scotistic thought represents an alternative to the Thomistic one. In Amoris Laetitia, Pope Francis demonstrates doctrinal continuity with the previous magisterium, although it somewhat innovates by focusing more on conjugal love than on the canonical aspects of the sacrament of matrimony, thus making room for new practices of the family apostolate.

KEYWORDS: Amoris Laetitia. Pope Francis. Duns Scotus. Conjugal Love.

\section{Introdução}

$\mathrm{O}$ quinto aniversário da exortação apostólica pós-sinodal Amoris Laetitia, promulgada na Solenidade de São José do ano 2016, será comemorado dentro do Ano de São José. Foi a festa litúrgica de São José o dia escolhido pelo Papa Francisco para inaugurar seu pontificado, em 2013. Para Francisco, São José é um ícone do pai e esposo cristão. E o fato de a Sagrada Família de Nazaré, inspiração para os cristãos de hoje, ser tão diferente das famílias tradicionais judaicas daquela época - um "matrimônio rato não consumado", um pai não biológico, um filho único em detrimento do padrão cultural que exigia prole numerosa - apenas confirma a intuição do Papa Francisco de que, na família, o amor deve sempre ser considerado anterior e mais importante que quaisquer outros de seus elementos constitutivos. Isso deve motivar a "Igreja em saída" a não ter medo de reconhecer a diversidade que permeia as famílias no mundo de hoje, reafirmando a doutrina do sacramento do matrimônio que nos é legada pela tradição, porém sem fazer desse ideal um instrumento de tortura a quem recebe rótulos de "casais irregulares" ou "famílias desestruturadas".

O próximo Encontro Mundial das Famílias, adiado por causa da pandemia para junho de 2022, em Roma, terá como tema "Amor familiar: vocação e caminho de santidade", aludindo simultaneamente às exortações Amoris Laetitia e Gaudete et Exsultate. O Papa Francisco, com essa escolha, mais uma vez insiste na primazia do cultivo e desenvolvimento do amor na família. Com isso, o Pontífice elege não só o elemento principal dos casamentos, mas também o que todos têm em comum, mesmo os "casos especiais" da pastoral familiar. Trata-se de uma postura decididamente inclusiva e integradora. Francisco defende que uma pessoa, mesmo vivendo numa situação dita irregular, "possa amar e possa também crescer na vida de graça e de caridade" (AL, n. 305). Assim, o papa ensina que a santidade não deve ser vista como uma questão de "tudo ou nada", mas como o maior esforço possível por se abrir à graça santificante. Afinal, como ele já havia dito, "um pequeno passo, no meio de grandes limitações humanas, pode ser mais agradável a Deus do que a vida externamente correta de quem transcorre os seus dias sem enfrentar sérias dificuldades" (EG, n. 44). 
Neste artigo, propomo-nos a identificar no ensino do Papa Francisco particularmente em sua exortação Amoris Laetitia - algumas das opções fundamentais características da Escola Franciscana. Um dos maiores nomes dessa corrente de teologia e espiritualidade é João Duns Scotus, nascido na Escócia em 1266 e falecido na Alemanha em 1308. Scotus ingressou na Ordem dos Frades Menores e tornou-se mestre de teologia, tendo lecionado em Oxford, Paris e Colônia. Morto aos 42 anos, não teve tempo de sistematizar sua vasta obra. Scotus é conhecido como "Doutor Sutil" devido à sua grande capacidade de aprofundar as questões filosóficas e teológicas debatidas na época, explorando-as a partir de várias perspectivas. Tendo vivido uma geração depois de Tomás de Aquino, Scotus teve sua obra ofuscada pela do Doutor Angélico, por esta ter se tornado praticamente a teologia oficial do papado. Mas o escotismo se manteve sempre vivo, ainda que quase sempre como um contraponto do tomismo.

Iniciaremos pautando, em linhas gerais, as preferências específicas da Escola Franciscana frente às da Escola Dominicana, já posicionando aí o magistério do Papa Francisco. Então, encontraremos na exortação Amoris Laetitia alguns elementos que apontam para a primazia do tema do amor, não em detrimento de, mas na relação com o da verdade. Mostraremos como essa abordagem parte, na obra de Scotus, da eleição da vontade - e não do intelecto - como potência primaz da alma. Veremos ainda como tal posicionamento desemboca no conceito de liberdade acima do de necessidade. Por fim, apontaremos aplicações pastorais que esse primado do amor sobre a verdade oferece nas obras de Duns Scotus e do Papa Francisco, especialmente em vista de uma renovada pastoral familiar, que tenha algo a dizer diante dos imensos desafios do nosso tempo.

\section{Os dois Franciscos: o santo e o papa}

Em seus documentos magisteriais, Jorge Bergoglio, como que confirmando na prática o significado do nome que escolheu para Romano Pontífice, demonstra predileção por temas tipicamente franciscanos. De fato, não é aleatório, por exemplo, que a encíclica Laudato Si' (2015), ao abordar a questão ecológica, ecoe o profetismo daquele santo de Assis proclamado patrono da ecologia; assim como não é irrelevante que em seu texto programático, a exortação apostólica Evangelii Gaudium (2013), o Papa Francisco tenha afirmado querer "uma Igreja pobre para os pobres" (EG, n. 198), à luz de seu santo onomástico, que desposou a "Dama Pobreza". Outra marca tipicamente franciscana adotada pelo papa é a alegria, conceito presente no próprio título de Amoris Laetitia, bem como já em Evangelii Gaudium e depois na exortação apostólica Gaudete et Exsultate. Como já fiz notar:

Em latim, as palavras gaudium e laetitia são praticamente sinônimas. A diferença é que gaudium é um sentimento mais interno, que se passa no recolhimento 
da alma, e laetitia é uma manifestação exterior de júbilo; na Suma Teológica ${ }^{1}$, S. Tomás de Aquino explica que a palavra laetitia vem de latitia, que significa "dilatar do coração" (ALMEIDA, 2018, p. 12-13).

São Francisco destoava do caráter soturno a que geralmente se associava a santidade na Idade Média. Seu senso de humor e sua visão positiva da vida e da fé o faziam sorrir e dançar, convidando as irmãs criaturas a rejubilar em Deus. Mas não se trata de uma alegria ingênua: no célebre relato das fontes franciscanas, o Pobrezinho de Assis ensina a Frei Leão que a "verdadeira e perfeita alegria" não está nos sucessos e prazeres, mas no despojamento total por amor a Deus e aos irmãos. Francisco imagina a possibilidade de serem ambos desprezados à porta do convento e não acolhidos depois de uma viagem, estando famintos e no frio da noite: "se suportarmos tal injúria e tal crueldade, tantos maus-tratos, prazenteiramente, sem nos perturbarmos e sem murmurarmos contra ele, [...] nisso está a perfeita alegria" (I Fioretti, cap. 8. In: FONTES Franciscanas e Clarianas, 2004, p. 1503). Em tempo: talvez esse conceito franciscano de "perfeita alegria" explique a paciência e serenidade do Papa Francisco em lidar com a agressividade de seus opositores, inclusive entre o episcopado e o colégio de cardeais. Essa alegria de São Francisco é exatamente a "Alegria do Amor" proposta pelo Papa Francisco. O amor mostra-se a grande motivação para a alegria franciscana, e o cerne de sua reforma da Igreja: amor de Deus, amor fraterno, amor às criaturas etc.

No início do século XIII, São Domingos de Gusmão fundava a Ordem dos Pregadores para enfrentar as heresias. No mesmo período, São Francisco de Assis fundava a Ordem dos Frades Menores porque "o amor não é amado". Já a partir daí se podem notar, ainda que em caricatura, dois caminhos distintos - e complementares - que se desenvolverão desde a teologia escolástica, no bojo dos ímpetos reformadores que essas duas ordens mendicantes emergentes ofereciam à Igreja: as chamadas Escola Dominicana e Escola Franciscana. Na primeira, destacaram-se sobretudo Alberto Magno e Tomás de Aquino; na segunda, principalmente Boaventura de Bagnoregio e João Duns Scotus.

A tradição filosófica antiga e medieval apontava a vontade e o intelecto como as duas potências da alma. Em seu tratado da Trindade, Tomás explica que "a processão do verbo pertence à ação do intelecto. [...] Além da processão do verbo, afirma-se, então, em Deus outra processão: é a processão do amor" (S.Th. I, q. 27, a. 3). "O que procede em Deus por modo de amor não procede como algo gerado, ou como filho, mas mais propriamente como um espírito" (S.Th. I, q. 27, a. 4). Assim, o intelecto do Pai gera o Verbo, que é o Filho, e da vontade do Pai (e do Filho) procede o Espírito Santo, que é o amor. Agostinho, em seu De Trinitate, já havia

${ }^{1}$ Cf. S.Th. I-II, q. 31, a. 3, ad. 3. 
defendido que a estrutura da alma humana, criada à imagem e semelhança de Deus, reproduz, de certa forma, a vida interna do Deus Trino².

Seguidores de Tomás de Aquino e de Duns Scotus sempre disputaram a respeito de qual dessas duas faculdades da alma teria o primado na psiquê humana: o intelecto ou a vontade. A Escola Dominicana, tendo em tomistas seus maiores expoentes, identifica-se, em geral, com o intelectualismo, por defender a primazia do intelecto; aos pensadores da Escola Franciscana, por sua vez, tendo à frente os escotistas, costuma-se atribuir o rótulo de voluntaristas ${ }^{3}$, devido principalmente à posição de Duns Scotus sobre o primado da vontade.

O Papa Bento XVI, mesmo tendo publicado importantes textos sobre o amor $^{4}$, optou fundamentalmente pelo enfoque à segurança da verdade ${ }^{5}$ frente ao que chamou de "ditadura do relativismo". O Papa Francisco, por sua vez, mesmo apresentando-se como em continuidade com o ensino de seu antecessor, sinaliza estar convicto de que o momento atual exige urgentemente pautar muito mais a caridade que a verdade. Para Bergoglio, a reforma de que a Igreja tanto necessita não ocorrerá ao se adicionarem doses maiores de clareza doutrinária ao cenário eclesiástico. O diagnóstico de Francisco sinaliza que a Igreja precisa agora investir todas as forças na saída de si, no cuidado dos vulneráveis da história, no testemunho de comunhão e acolhida. A hora é de uma verdadeira revolução do amor. A ideia de Ecclesia semper reformanda que Bergoglio trouxe consigo da Argentina para a Santa Sé combina fundamentalmente com a que o seu santo homônimo empreendeu: o que está em jogo é muito mais que uma reforma administrativa na Cúria Romana ou uma auditoria no "banco do Vaticano". A questão é mudar o foco, das instituições para as pessoas. É como um bombeiro que se empenha em salvar antes os moradores que o prédio em chamas. O primado do amor no magistério papal de Francisco, longe de negligenciar a verdade, liberta-a da carga legalista e rubricista que não encontra mais espaço no mundo atual.

Francisco, na Amoris Laetitia repete insistentemente a palavra amor: ela aparece 367 vezes ao longo do texto, sem contar as 30 vezes em que surge seu sinônimo caridade, além das diversas outras palavras derivadas de amor: amoroso, enamorado etc. Especialmente no Capítulo IV, Francisco menciona o termo à exaustão, falando do amor conjugal, do enamoramento, da amizade e da caridade cristã. Mais recentemente, na encíclica Fratelli Tutti (2020), é possível mais uma vez perceber na teologia de Francisco

${ }^{2}$ Cf. De Trin. X, 11, 18; PL 42, p. 983.

${ }^{3}$ Como se verá adiante, não é acurada a atribuição de voluntarismo à obra de Scotus.

${ }^{4}$ Deus Caritas est, Caritas in Veritate e Sacramentum Caritatis são exemplos.

${ }^{5} \mathrm{O}$ lema episcopal de Joseph Ratzinger expressa bem tal opção: "Colaborador da Verdade" (3Jo 8). 
a primazia da caridade sobre a verdade ao falar do "amor social" ou da "amizade social" sobre quaisquer contratos sociais meramente jurídicos. Amoris Laetitia (daqui em diante, AL) e Fratelli Tutti enaltecem o amor humano, fruto da experiência com o amor divino, em suas duas encarnações mais proeminentes: a família e a sociedade.

\section{Amoris Laetitia: o amor antes que a doutrina}

Ao abordar os temas matrimônio e família na AL, Francisco opta clara e decididamente por enfocar o amor conjugal ao invés de manter as ênfases anteriores no caráter canônico e mesmo teológico do sacramento do matrimônio. É nesse sentido que ele afirma, no Capítulo III: “O nosso ensinamento sobre o matrimônio e a família não pode deixar de se inspirar e transfigurar à luz deste anúncio de amor e ternura, se não quiser tornar-se mera defesa duma doutrina fria e sem vida" (AL, n. 59). Assim, para o papa, uma pastoral familiar eficaz há que acompanhar os fiéis casados no sentido de ajudá-los a cultivar e desenvolver o amor, muito mais do que insistindo numa manutenção meramente jurídica do vínculo; isso porque, sendo o amor conjugal a "alma" do casamento, um apostolado matrimonial que se ocupasse apenas do "corpo" - fidelidade, indissolubilidade, prole... - correria o risco de, por fim, estar garantindo meramente a sustentação de um cadáver. O amor, única força capaz de sustentar relacionamentos conjugais de longo prazo em meio à cultura contemporânea do descartável e da fugacidade, claramente deve ter o primado sobre a unidade, a fidelidade e a abertura à procriação, verdades inquestionáveis com as quais os nubentes se comprometem ao se unirem em matrimônio.

Adiante, o Santo Padre diz, no mesmo sentido: "Não poderemos encorajar um caminho de fidelidade e doação recíproca, se não estimularmos o crescimento, a consolidação e o aprofundamento do amor conjugal e familiar" (AL, n. 89). Para Francisco, a prioridade neste nosso tempo deve ser uma abordagem pastoral, concreta e, consequentemente, mais realista do matrimônio, uma vez que a postura de se reafirmar a doutrina não tem conseguido mitigar os graves efeitos da crise que as famílias enfrentam desde a revolução sexual dos anos 1960. Essa ênfase na pastoral se dá pelo fato de Francisco, como frequentemente se aponta, ser até hoje o pontífice mais comprometido com a aplicação do Vaticano II, tendo este último concílio um perfil muito mais pastoral do que doutrinal.

No Capítulo IV da AL, Francisco volta a defender sua ênfase: “O amor matrimonial não se estimula falando, antes de mais nada, da indissolubilidade como uma obrigação, nem repetindo uma doutrina, mas robustecendo-o por meio dum crescimento constante sob o impulso da graça." (AL, n. 
134). Mesmo argumentando numa perspectiva tomista, se a própria verdade está em desenvolvimento - "Não que ela própria seja o sujeito dessa mudança, mas pelo fato de que nosso intelecto passa do verdadeiro ao falso" (S.Th. I, q.16, a.8) -, muito mais a caridade, "que não tem limites no seu crescimento, pois ela é uma participação da caridade infinita que é o Espírito Santo" (S.Th. II-II, q.24, a.7). Portanto, para o Papa Francisco, uma pastoral familiar eficaz é aquela que acompanha os cônjuges no caminho de crescimento e amadurecimento do amor, que "não é apenas um sentimento" (AL, n. 94), pois sabe "ultrapassar os sentimentos" (AL, n. 119). Enfatizar a vivência possível do amor conjugal ao invés de idealizar a doutrina acerca do matrimônio nada tem de relativista ou voluntarista, ou mesmo em prejuízo da verdade. Trata-se, isso sim, de começar pelas "motivações" - de caráter mais existencial - para o vínculo matrimonial e não pelos "motivos" - de per se mais racionais.

Como se pode perceber, ao longo do texto, o papa centra seus esforços na caridade, ora como virtude teologal a ser pedida a Deus, ora como virtude humana a ser desenvolvida pelos esposos e filhos. Como veremos, num silogismo, o primado do amor sobre a verdade, na tradição da Escola Franciscana, é consequente com a primazia da liberdade sobre a necessidade. Quando Jesus explicitou a doutrina imutável da indissolubilidade matrimonial, "os discípulos disseram-se: 'Se é assim a condição do homem em relação à mulher, não vale a pena casar-se'" (Mt 19,10). A resposta de Jesus, na sequência, dá conta de que os compromissos do matrimônio apenas podem ser compreendidos e vividos numa perspectiva vocacional: a quem for chamado por Deus ao amor conjugal, o sacramento do matrimônio jamais será um fardo difícil de levar, porque será sempre fruto do exercício da liberdade, e não uma imposição que escraviza. Como ensina o Papa Francisco, "o matrimônio é uma questão de amor: só se podem casar aqueles que se escolhem livremente e se amam" (AL, n. 217).

Segundo Tomás, o matrimônio "consiste na união de homem e mulher destinada à geração e educação da prole para o culto de Deus e para os sacramentos" (S.c.G. IV, c. 78, n. 3). O Código de Direito Canônico afirma: "A aliança matrimonial, pela qual homem e mulher constituem entre si uma comunhão da vida toda, é ordenada por sua índole natural ao bem dos cônjuges e à geração e educação da prole" (Cân. 1055, §1). Embora as expressões união, aliança, comunhão e bem dos cônjuges apontem para a realidade do amor conjugal, a ênfase, nesse tipo de abordagem, comum nos documentos eclesiásticos, está mais na verdade que obriga do que no amor que motiva o vínculo matrimonial. O que o Papa Francisco faz em Amoris Laetitia é justamente recuperar o projeto inicial do Criador para a dimensão sexual humana: "Não é bom que o homem esteja só. Vou fazer uma auxiliar que lhe corresponda" (Gn 2,18). O amor conjugal funda-se numa complementaridade entre mulher e homem antes afetiva que sexual, mais ocupada em vencer a solidão do que em preservar a manutenção da espécie. 
A seguir, trataremos de comparar Duns Scotus e Tomás de Aquino em suas opiniões sobre a relação do amor com a verdade. Faremos isso, contudo, não para contrapor um ao outro, mas para, diante do paradigma filosófico-teológico dominante no ocidente, que é o tomismo, destacar a especificidade e originalidade do pensamento escotiano ${ }^{6}$, que tem sido chamado a dar uma importante e alternativa contribuição à teologia do nosso tempo, com seus primados da vontade sobre o intelecto, da caridade sobre a verdade e da liberdade sobre a necessidade.

\section{Scotus e o primado da vontade sobre o intelecto}

Para Tomás, o desejo humano está necessariamente orientado ao seu fim, a saber, a felicidade plena que consiste em Deus somente. Portanto, se não houvesse um fim último, nada seria desejado pelo ser humano (S.Th. I-II, q. 1, a. 4); a essência da felicidade consiste num ato do intelecto e não da vontade (Ibid., q. 3, a. 4); a felicidade consiste numa operação do intelecto especulativo, pois Deus é objeto não do intelecto prático e sim do especulativo, e a perfeita felicidade consiste na contemplação (Ibid., a. 5); a felicidade final é a visão da essência divina (Ibid., a. 8); aqueles que estão na felicidade da visão beatífica não podem mais pecar (Ibid., q. 5, a. 4); e apenas quem não sabe que a felicidade plena consiste em ver a Deus poderia não desejá-lo (Ibid. a. 8). Como se percebe, o funcionamento de todo o sistema ético tomasiano passa por verdades necessárias e pela primazia do intelecto.

A posição de Tomás a respeito das relações entre o intelecto e a vontade é, como ele mesmo afirma, a de que "essas duas potências se implicam mutuamente em seus atos: pois o intelecto conhece que a vontade quer, e a vontade quer que o intelecto conheça" (S.Th. I, q. 82, a. 4). Porém, "o objeto do intelecto é superior ao objeto da vontade; [...] o intelecto, em si mesmo e absolutamente, é uma potência superior e mais nobre que a vontade" (S.Th. I, q. 82, a. 3). E mais: “a última felicidade do homem está substancialmente em conhecer a Deus pelo intelecto, não no ato da vontade" (S.c.G. III, 26). Assim, o Sumo Bem ao qual o desejo humano está orientado é a visão beatífica, uma atividade do intelecto especulativo e não do intelecto prático, como já dito acima. Ou seja, o fim último da vida humana, para Tomás, é contemplar a luz de Deus com o intelecto.

\footnotetext{
${ }^{6}$ Neste artigo, optamos pela distinção entre conceitos escotianos - do próprio Scotus, encontrados em seus textos autógrafos - e escotistas - i.e., de seus discípulos ou estudiosos de épocas posteriores. Para estabelecer um paralelo com essa nomenclatura preferimos usar, referindo-nos a Tomás de Aquino, o termo tomasiano (e não "tomásico", mais comum) ao nos reportarmos ao que o próprio Doutor Angélico escreveu, e tomista à escola que se desenvolveu a partir do pensamento de Tomás.
} 
Para Scotus, diferentemente, a ética se dá num panorama de liberdade e contingência. Para ele, mesmo se Deus não existisse, continuaria a haver o sumo bem, o bem em si, pois o que é bom em si mesmo não se identifica necessariamente com Deus. Para Scotus, ao invés da natureza e da necessidade, a base do ser é a liberdade e a contingência. Isso desloca o centro de todo o pensamento escotiano do intelecto para a vontade. Neste novo quadro, a felicidade suprema é buscada por ser um bem e não por ser necessariamente Deus. "A vontade quer livremente o fim; por isso ela não pode querer o fim por necessidade natural"7, diz Scotus. Além disso, "se todos os atos da vontade fossem dirigidos para a felicidade, o homem não agiria livremente, mas ao modo de natureza. [...] Também não seria possível imputar o pecado, pois o pecado só é imputável se ele é evitável" (CEZAR, 2010, p. 33).

$\mathrm{Na}$ verdade, Scotus jamais separa a vontade da razão, o que muitos erroneamente o acusaram de fazer. Scotus apenas afirma que a vontade é distinta do intelecto e lhe tem a primazia; porém, não hesita em declarar que a vontade é "um apetite com razão livre"8, é um "apetite racional"; e que "ter vontade e ser natureza intelectual coincidem"10. Da mesma forma, o conceito de amor conjugal utilizado pelo Papa Francisco nada absolutamente tem de arbitrário e oposto à racionalidade. Diz ele:

Não é possível prometer que teremos os mesmos sentimentos durante a vida inteira; mas podemos ter um projeto comum estável, comprometer-nos a amar-nos e a viver unidos até que a morte nos separe, e viver sempre uma rica intimidade. $\mathrm{O}$ amor, que nos prometemos, supera toda a emoção, sentimento ou estado de ânimo, embora possa incluí-los. É um querer-se bem mais profundo, com uma decisão do coração que envolve toda a existência $(\mathrm{AL}, \mathrm{n} .163)^{11}$.

Para Scotus, "a vontade divina é a causa do que é bom e porque ele [Deus] quer algo, este algo é bom"12; ou seja, da mesma forma como as coisas são inteligíveis porque Deus primeiramente as intelige (Ord. I, d. 35, n. 31-32), assim também um ato moral é considerado bom e meritório porque Deus primeiramente assim o quis. Para Scotus, o bem é fundamentalmente ser, e o mal é não ser. Por isso, ao afirmar que as coisas são boas porque Deus assim o quer, ele está apenas ressaltando que "as coisas finitas não possuem em si mesmas uma bondade tal que Deus se veja obrigado a criá-las. Ele já é infinitamente bom e não se torna melhor ao criar as coisas finitas com a bondade finita delas" (CEZAR, 2014, p. 61).

\footnotetext{
7 "Voluntas libere vult finem ergo non potest necessitati naturali vele finem" (Ord. I, p. 2, q. 2, n. 80). 8 "appetitus cum ratione liber" (Ord. III, d. 17, q. un., n. 2).

9 "appetitus rationalis" (Ord. III, d. 33, q. un., n. 9).

10 "habere voluntatem et esse naturam intellectualem convertuntur" (Ord. IV, d. 49, q. 2, n. 20).

${ }^{11}$ Não deixa de ser curioso e belo notar que o papa usa aqui a primeira pessoa do plural não no sentido do clássico "plural majestático" que muitos pontífices usavam no passado, mas para evidenciar o caráter humano e comum da experiência do amor, na qual ele próprio se inclui. 12 "voluntas divina est causa boni, et ideo eo ipso quod vult aliquod, ipsum est bonum" (Rep. Par. I, d. 48, q. un.; ed. Vivès XXII, p. 512).
} 
Scotus jamais relacionou a vontade a alguma ruptura com a ordem racional nem propôs a noção de uma vontade divina autoritária e sem critérios ${ }^{13}$. Para ele, o termo vontade refere-se não a uma "parte" da pessoa, mas à pessoa como um todo, que é simultaneamente racional e livre. Segundo Copleston, "a acusação que tem sido trazida contra [Scotus] de ensinar o caráter puramente arbitrário da lei moral, como se esta dependesse única e exclusivamente da vontade divina, é fundamentalmente uma acusação injusta" (COPLESTON, 1993, p. 546). A verdade é que, para Scotus, dizer que um ato da vontade é bom significa simplesmente afirmar que tal ato está em conformidade com a reta razão. Em suma, o que Deus quer é bom porque a vontade de Deus é idêntica à sua bondade, o que faz com que Deus não possa querer algo que não seja bom, pois nele intelecto e vontade se identificam com sua própria essência, e não pode haver contradição entre eles. Trata-se, pois, não de separar o intelecto da vontade, mas de compreender que ordem elas seguem na alma.

O atual Ministro Geral da O.F.M. explica:

Para Scotus e para os franciscanos, o fim da existência humana não consiste tanto na eterna contemplação da perfeição divina quanto no empenho intenso e progressivo em amar a Deus sobre todas as coisas, e ser amado por Ele, e amar-se e sustentar-se reciprocamente. Aqui não há visão beatífica. Aqui há abraço beatífico, um continuum de amor, que se estende a todos (PERRY, 2017, p. 2).

Duns Scotus, como bom seguidor de Francisco de Assis, tende sempre a afirmar o amor como centro gravitacional de toda a criação. No prólogo da Ordinatio, Scotus defende que a teologia é uma ciência prática e não teórica: "Quando se trata daquelas verdades que verdadeiramente são vistas como teológicas e não metafísicas, como 'Deus é trino', 'o Pai gera o Filho', digo que estas verdades são práticas"14. Isso porque "a fé não é um hábito especulativo, nem crer é um ato especulativo, nem a visão que segue o crer é especulativa, mas prática, pois esta visão é feita para ser conforme à fruição"15. Para Scotus, a teologia tem como finalidade um ato volitivo: amar a Deus, que é mais que um ato intelectivo (contemplá-lo ou conhecê-lo). Isso vale não somente para os bem-aventurados, que fruem a visão beatífica, mas também para os que ainda estamos no mundo como peregrinos, pois o pensar teológico existe para ser mais performativo que formativo. E em vista dessa preferência que Scotus defende que a união entre amante e amado é mais perfeita do que entre cognoscente e cognos-

\footnotetext{
13 "A vontade não é a irracionalidade, como se pretendeu afirmar muitas vezes, sobretudo na filosofia moderna, invocando erroneamente o nome de Scotus" (OROMÍ, 1960, p. 86). 14 "Cum instatur de illis veritatibus, quae verissime videntur theologicae et non metaphysicae, 'Deus est trinus', 'Pater generat Filium', dico quod istae veritates sunt practicae” (Ord. Prol., p. 5, q. 2, n. 322). 15 "fides non est habitus speculativus, nec credere est actus speculativus, nec visio sequens credere est speculativa, sed practica; nata est enim illa visio conformis esse fruitioni" (Ibid., n. 345).
} 
cível; e por isso, a felicidade plena consiste mais em amar o Ser Infinito do que conhecê-lo. Diz o Doutor Sutil:

Um ato não é perfeito se não se unir a um objeto perfeito. Ora, um ato da vontade se une ao que já está em si, enquanto um ato do intelecto, não (a menos que este já esteja no cognoscente). Logo, um objeto absolutamente beatífico é mais nobre em si do que o objeto do cognoscente. Portanto, o ato da vontade une-se ao objeto absolutamente beatífico sob um aspecto mais nobre ${ }^{16}$.

Isto se deve ao fato de que o ato da vontade une mais estreitamente o sujeito ao objeto do que o ato do intelecto; ou seja, o amor, por si só, independentemente do objeto amado, é mais vinculante do que a razão. Mais me aproxima de uma coisa o ato de amá-la do que o de conhecê-la. $\mathrm{O}$ amor, como ato volitivo, tem autonomia sobre todo e qualquer ato intelectivo, até porque a própria vontade possui, em si, uma racionalidade. Eu posso me determinar pela vontade a conhecer melhor uma pessoa, e tal conhecimento se dá de fato, mas conhecer melhor uma pessoa não é suficiente para que eu a ame mais; pode inclusive acontecer o contrário; o que prova que a vontade tem mais autonomia do que o intelecto.

Scotus explica que a primazia temporal do intelecto em relação à vontade se deve ao fato de que, para querer, a alma precisa antes conhecer; afinal, não se ama o que não se conhece, o que é lógico. Mas para sustentar a superioridade da vontade em relação ao intelecto, Scotus recorre à lei universal pela qual o mais perfeito nasce sempre do menos perfeito. Ora, se perfeito é o mais completo, então o perfeito deve vir depois do menos completo. Portanto, o ato intelectivo está ordenado ao ato volitivo que, por isso mesmo, lhe é superior. Para Scotus, é impossível que a vontade seja violentada; pode-se forçar alguém a praticar um ato, mas nunca a querer tal ato. Além disso, diz Scotus, "não se diz que uma ação do intelecto é má, pois não está em poder do intelecto escolher a intelecção, o que é uma imperfeição, mas é uma perfeição da vontade que um ato seu possa ser mal ou impuro"17. A vontade pode controlar suas próprias inclinações, por exemplo, escolhendo abster-se do que desejou; por outro lado, "não está em poder do intelecto moderar seu assentimento ao verdadeiro que ele apreende" ${ }^{18}$. Por ser uma potência não livre, mas do necessário, o intelecto não pode deixar de dar seu assentimento a algo verdadeiro e nem deixar de inteligir um mau pensamento que se lhe apresenta. $\mathrm{O}$ intelecto

\footnotetext{
16 "actus non est perfectus nisi quia coniungit cum obiecto perfecto; actus autem voluntatis coniungit in se ut in se est, actus autem intellectus non, nisi ut est in cognoscente. Obiectum autem beatificum simpliciter nobilius est in se quam ut est in cognoscente; ergo actus voluntatis coniungit obiecto beatifico simpliciter sub nobiliori ratione" (Ord. IV, d. 49, p. 1, q. 4, n. 260).

17 "actio intellectus non dicitur mala, quia non est in potestate intellectus eligere intellectionem, et hoc est imperfectionis, sed ex voluntatis perfectione est quod actus suus possit esse malus e impurus" (Rep. Par. IV, d. 49, q. 2; ed. Vivès XXIV, p. 629).

18 "non est in potestate intellectus moderare assensum suum veris, quae apprehendit" (Ord. II, d. 6, q. 2, n. 10).
} 
depende da vontade, pois "uma ação é racional se for livre e na medida em que faz crescer a liberdade" (TODISCO, 2014, p. 165). A vontade e o intelecto causam juntos o ato de volição, sem que um dependa do outro nessa causalidade. Conhecemos aquilo que já queremos, e que, uma vez conhecido, passa a ser querido com mais intensidade (Ibid., p. 168). Além disso, a vontade mostra-se superior porque sua corrupção é pior que a corrupção do intelecto; e também porque "odiar a Deus é pior que não conhecer a Deus ou não pensar em Deus. Igualmente, o pecado significa querer algo mau, enquanto pensar em algo mau não é necessariamente um pecado" (COPLESTON, 1993, p. 540), o que prova que a vontade é mais nobre que o intelecto, pois tem mais poderes que ele.

Na AL, o Papa Francisco conclama os pastores de almas a dialogar com os casais em situações "irregulares", a acolhê-los, a formar sua consciência (ao invés de pretender substituí-la! [AL, n. 37]) e a acompanhá-los num caminho de discernimento espiritual em vista do maior grau possível de integração deles na comunhão eclesial. Trata-se, evidentemente, não apenas de aplicar o intelecto à descoberta de uma verdade preestabelecida, do tipo "posso ou não posso comungar", mas sim de um exercício em que a vontade, com sua racionalidade interna acionada, partindo da verdade universal, pondera cada situação particular em busca de uma resposta que corresponda, o mais possível, simultaneamente ao bem comum da Igreja e ao bem das pessoas. Se a justiça fosse meramente a aplicação de um ato do intelecto do legislador, precisaríamos apenas de leis; no entanto, se precisamos também da decisão de juízes com consciência bem formada para aplicar tais leis, isso quer dizer que dependemos também e sobretudo da vontade. O método ver-julgar-agir, tão conhecido nosso na Igreja da América Latina e do Caribe, e que o Papa Francisco introduziu em seu magistério papal, mostra que o "ver" (intelecto) surge por primeiro, no sentido linear-temporal, mas que conduz ao binômio "julgar-agir" (vontade), que, portanto, tem o primado.

\section{0 primado da liberdade sobre a necessidade}

Como nota Sinivaldo Tavares, "ao privilegiar a vontade sobre o intelecto, Scotus põe ao centro não a verdade, mas a liberdade" (TAVARES, 2010, p. 99). Na filosofia ética escotiana, a liberdade da ação é sempre muito assegurada e garantida; é possível até mesmo agir necessariamente sem perder a liberdade. Scotus recorre ao sentido da visão como exemplo disso. Embora os olhos vejam necessariamente, eles veem primeiramente porque o vidente decide mantê-los abertos para ver. "Digo 'ver livremente' porque livremente posso usar a potência da visão para ver"19, diz o Doutor Sutil.

19 "Ego dico 'libere videre' quia libere possum uti potentia visiva ad videndum" (Lec. II, d. 25, q. un., n. 74). 
Ou seja, "temos olhos para ver, os quais são preciosos instrumentos da visão. E, todavia, não vemos apenas porque temos olhos, mas sim porque queremos ver. [...] Se decidirmos não ver, o fato de termos olhos é irrelevante" (TODISCO, 2014, p. 163). Portanto, a vontade está na base de todo o agir humano; e o ser humano não é escravo da natureza, e mesmo o agir natural como a visão se submete, antes de tudo, a atos volitivos.

Scotus distingue a vontade natural da vontade livre. A vontade natural deseja necessariamente a felicidade em Deus, como afirma Tomás. Mas a vontade livre não deseja necessariamente Deus como fim último. Para Scotus, até mesmo no céu, os bem-aventurados amam a Deus livremente. Assim ele difere de Agostinho - para o qual, no céu, os bem-aventurados não podem não pecar ${ }^{20}$ - e de Tomás, para o qual Deus, como Sumo Bem, é amado necessariamente, isto é, pela imposição natural do Que ele é. Scotus chega ao ponto de afirmar que mesmo os bem-aventurados conservam a possibilidade de pecar, posto que a vontade continua sendo livre mesmo no céu. É claro que os bem-aventurados não pecarão, mas isso se deve à inclinação livre produzida pela vontade, e não por uma necessidade, que é da ordem do natural.

Para descrever a vontade livre e autônoma, Scotus usa mais frequentemente o termo contingência, que, para ele, não é apenas liberdade como contraponto de natureza, mas também e sobretudo como gratuidade: "Não chamo contingente a qualquer não-necessário ou não-eterno, mas àquele cujo oposto pode acontecer quando ele acontece" 21 . Portanto, dizer que a criação é contingente significa dizer que só Deus é necessário, tudo o mais poderia não ser como é, e mesmo poderia nem ser. Num trecho particularmente difícil, Scotus afirma que a vontade "quer livremente, e ela não 'quer livremente' a não ser porque pode desquerer" ${ }^{22}$ : ainda que o agir humano tenha como causa final a razão, sua causa eficiente é a vontade indeterminada, que é essencialmente livre ${ }^{23}$.

O primado da liberdade-contingência sobre a necessidade torna-se perceptível principalmente na abordagem de Scotus à pergunta Cur Deus

\footnotetext{
20 "Prima ergo libertas voluntatis erat posse non peccare; novissima erit multo maior: non posse peccare" - "A primeira liberdade da vontade era poder não pecar; a última será muito maior: não poder pecar" (De cor. grat. I, 12, 33; PL 44, p. 936).

21 "non voco hic contingens quodcumque non necessarium vel non sempiternum, sed cuius oppositum posset fieri quando illud fit" (Ord. I, d. 2, p. 1, q. 1-2, n. 86).

22 "si ponitur voluntatem esse tantum in uno instante, libere vult, et non 'libere vult' nisi quia potest nolle" (Lec. I, d. 39, q. 5, n. 52; trad. R. H. Pich. In: SCOTUS. Textos sobre poder, conhecimento e contingência. Porto Alegre: EdiPUCRS; Editora Universitária São Francisco, 2008, p. 112).

${ }^{23}$ Segundo Scotus, nem mesmo a virtude teologal da caridade antecede a vontade no ato de amor, mas a segue na ordem causal: “Não é a caridade o principal movente nem agente no ato do amor, mas a vontade. [...] A vontade é causa anterior e principal daquele ato, e a caridade [é a causa] segunda e menos principal" - "Ideo dico quod caritas non est principale movens nec agens in actu diligendi, sed voluntas. [...] Voluntas est causa prior et principais respectu illius actus, et caritas secunda et minus principais" (Lec. I, d. 17, p. 1, q. un., n. 76).
} 
homo (Por que Deus se fez homem?) A resposta de Anselmo de Cantuária e Tomás de Aquino a essa questão clássica é bastante conhecida: o Filho se encarnou por causa do pecado humano; e se Adão e Eva não tivessem pecado, o Verbo não teria tido "necessidade" de se encarnar. Por sua vez, Scotus, ao se perguntar como Cristo foi predestinado a ser Filho de Deus, quer saber, antes de tudo, "se esta predestinação prevê necessariamente a queda da natureza humana, - o que parecem dizer muitas autoridades, que afirmam que o Filho de Deus nunca se teria encarnado se o ser humano não caísse ${ }^{\prime \prime 24}$. A resposta oferecida pelo Doutor Sutil, seguindo a preferência franciscana pela via amoris sobre a via iustitiae, vê a história da salvação sob a ótica não do pecado e sua necessidade de justiçamento, mas do amor: "Parece muito irracional que Deus deixasse de fazer tão grande obra por causa de um bem feito por Adão, isto é, se ele não pecasse" 25 . Portanto, a obra prima de Deus, o Filho encarnado, não poderia ser causada por uma necessidade imposta a Deus, que é sumamente livre.

O Papa Francisco, seguindo a mesma ideia norteadora do pensamento escotiano, ensina que "quanto mais íntimo e profundo for o amor, tanto mais exigirá o respeito pela liberdade e a capacidade de esperar que o outro abra a porta do seu coração" (AL, n. 99). Essa identificação do amor com a liberdade e a gratuidade é o que nos diferencia das outras espécies do reino animal, que não conseguem romper a cadeia dos instintos da natureza. Portanto, a maior especificidade que o sacramento do matrimônio tem frente ao modo natural de acasalamento das criaturas em geral é justamente o amor, que a doutrina católica acrescentou e antepôs ao "dever de gerar e educar a prole" com a expressão "o bem dos cônjuges". Em tempos como o nosso, em que toda a civilização ocidental milita fortemente contra todo tipo de sexismo e violência patriarcal ${ }^{26}$, o enfoque na liberdade ao se falar de sexualidade humana é fundamental. "O amor confia, deixa em liberdade, renuncia a controlar tudo, a possuir, a dominar" (AL, n. 115), ensina o papa.

\section{O primado da caridade sobre a verdade}

Como uma inferência da primazia escotiana da vontade sobre o intelecto, afirma-se também a da caridade sobre a verdade. Scotus "não vincula Deus à objetividade do verdadeiro" (TODISCO, 2010, p. 223), mas à liberdade

\footnotetext{
24 "utrum ista praedestinatio praeexigat necessario lapsum naturae humanae, - quod videntur sonare multae auctoritates, quae sonante Filium Dei numquam fuisse incarnatum si homo non cecidisset" (Ord. III, d. 7, q. 3, n. 60).

25 "quod tantum opus dimisisset Deus propter bonum factum Adae, puta, si non peccasset; videtur valde irrationabile" (Rep. Par. III, d. 7, q. 4; ed. Vivès XXIII, p. 303).

${ }^{26}$ Vide os movimentos \#MeToo e \#NãoÉNão, de grande abrangência, principalmente em hashtags nas redes sociais.
} 
do amor infinito. Conforme o próprio Doutor Sutil afirma na Ordinatio, "Deus é caridade e amor de modo formal, não apenas efetivamente" 27 , ou seja, ele é amor em si mesmo, não apenas ad extra. Na Lectura ele explica o que significa ser Deus formalmente caridade: "paciência, fé e esperança falam de imperfeição; portanto, não as predicamos formalmente de Deus. Pois Deus é formalmente amor e caridade" ${ }^{28}$. Enquanto essas outras virtudes são relativas - no sentido de serem referidas a outrem -, a caridade é absoluta, por ser a própria perfeição e a essência divinas. Enquanto essas outras virtudes apenas se manifestam no agir de Deus, a caridade é a sua própria substância. Richard Cross explicita que, em Scotus, mesmo as "verdades necessárias [...] são trazidas à existência por Deus" (CROSS, 1999, p. 51). Também segundo Todisco, "Scotus fala de produção [...] das verdades" (TODISCO, 2010, p. 224). Logo, no pensamento escotiano, não é a verdade que cria o amor, mas justamente o inverso: é o amor que cria a verdade. Para Scotus, as coisas não existem por serem racionais ou verdadeiras, mas por serem queridas gratuitamente por Deus.

Na Reportatio Parisiensis, Scotus pretende aplicar a primazia da vontade sobre o intelecto às noções do bom e do verdadeiro. Os escolásticos definem que a verdade está acima da bondade e do amor por estar mais próximo do ser; o Doutor Sutil discorda disso, alegando: "O bom é por essência bom, e absolutamente bom; o verdadeiro, porém, não é bom a não ser por participação" ${ }^{29}$. Robert Prentice comenta essa discussão, verificando que, para Scotus, "o bom, que é o objeto da vontade, é essencialmente bom; e o verdadeiro, que é o objeto do intelecto, é bom apenas por participação. Portanto, o bom é mais nobre que o verdadeiro" (PRENTICE, 1968, p. 77). Porém, não se trata de inferiorizar a verdade e a racionalidade em nome de uma liberdade arbitrária e irresponsável. A prioridade que a caridade tem em relação à verdade, na teologia escotiana, mostra que "a vontade transcende, não nega, o intelecto, como a liberdade não contradiz o pensamento" (TODISCO, 2008, p. 859). Assim, é necessário encontrar a verdade dentro da caridade. Como escreve Bento XVI, é necessário conjugar a caridade com a verdade: "a verdade há de ser procurada, encontrada e expressa na 'economia' da caridade" (CV, n. 2), pois "sem verdade, a caridade cai no sentimentalismo" (Id., n. 3). Porém, a verdade sem caridade nem sequer pode existir de fato, pois seria apenas uma "meia verdade". A própria teologia do sacramento do matrimônio prova isso: sem um amor seguido de verdade e liberdade, não há consentimento que garanta a validade do sacramento.

27 "Deus sit formaliter caritas et dilectio, - non tantum effective" (Ord. I, d. 17, pars 1, q. 1-2, n. 173). 28 "Sed patientia, fides et spes imperfectionem dicunt, et ideo non praedicantur formaliter de Deo. Deus igitur formaliter est dilectio et caritas" (Lec. I, d. 17, pars 1, q. un., n. 115).

29 "bonum est per essentiam bonum, et absolute bonum; verum autem non est bonum, nisi participatione boni" (Rep. Par. IV, d. 49, q. 2; ed. Vivès XXIV, p. 624); grifo nosso. 
Outro marco importante é que, na teologia de Scotus, a graça se identifica verdadeiramente com a caridade: "A graça é formalmente uma virtude, que é a caridade; e o que quer que seja atribuído de excelência à graça é atribuído também à caridade, e vice-versa" ${ }^{\prime 30}$. Ou seja, para Scotus, a caridade não é uma graça entre outras, mas a própria graça enquanto tal. Como diz a antiquíssima antífona do lava-pés, ubi caritas ibi Deus est ("onde está a caridade, Deus aí está"). Somente uma teologia da graça desse porte poderia possibilitar ao Papa Francisco a propor, no polêmico Capítulo VIII de AL - embora em notas de rodapé, justamente para não parecer que estivesse propondo uma mudança na doutrina -, a necessidade de acompanhar os cristãos em nova união civil após o divórcio, para ajudá-los no discernimento a respeito da real situação de sua consciência diante de Deus. Se a teologia moral católica, por tradição, sempre reconheceu o conceito de atenuantes em questões de foro interno, é porque graça e amor podem ser intercambiáveis, e porque a presença ou ausência da graça na alma de um fiel não é algo medido com réguas jurídicas, mas discernido mediante direção espiritual (AL, n. 301). Se graça é caridade e caridade é misericórdia, não se pode impor sobre o Deus sumamente livre um tal conceito de "mal intrínseco", tão engessado e rígido, que o faça refém de condenações necessárias e eternas.

\section{Conclusão}

Neste artigo, procuramos demonstrar como, em seu magistério - particularmente na Amoris Laetitia - o Papa Francisco, mesmo citando várias vezes Tomás de Aquino, transita mais entre os enfoques teológicos da Escola Franciscana do que os da Escola Dominicana. Sobretudo no modo como privilegia a alegria e o amor em seus escritos, o Sumo Pontífice propõe a verdade como que estando contida no arcabouço da caridade, esta tendo o primado e sendo para onde tende aquela.

Para Scotus, está bem claro que não é a verdade que cria o amor, mas o amor que cria a verdade. De fato, os binômios amor-verdade, vontade-intelecto ou misericórdia-justiça, por exemplo, são recorrentes na Escritura, tendo sempre o primeiro termo, também lá, o primado: "as sendas de Iahweh são todas amor e verdade" (S1 25[24],10); "a misericórdia triunfa sobre o julgamento" (Tg 2,13); "fé, esperança e amor; mas o maior deles é o amor" (1Cor 13,13); "a paz de Deus [...] guardará os vossos corações e os vossos pensamentos no Cristo Jesus" (Fl 4,7) etc. Para o Papa Francisco, no mesmo sentido, o amor conjugal é que é a fonte das verdades

30 "Gratia formaliter est virtus, quae est caritas; quia quaecumque excellentiae attribuuntur caritati, et gratiae, - et e converso" (Ord. II, d. 27, q. un., n. 8). 
sacramentais do matrimônio. Por isso mesmo, esse amor dos esposos deve ser a prioridade numa pastoral familiar. Não é por acaso que "alguns intérpretes da Amoris Laetitia, autorizados e recomendados pelo próprio Papa Francisco, têm dito que o capítulo 4 [...] é o pressuposto essencial para a correta compreensão do capítulo 8" (ALMEIDA, 2018, p. 21); pois é justamente no quarto capítulo, de longe o mais extenso dos 9 capítulos da exortação, que Francisco desenvolve o tema da caridade conjugal, com uma minuciosa exegese de 1Cor 13. Nesse capítulo em questão, o papa afirma que "na própria natureza do amor conjugal, existe a abertura ao definitivo" (AL, n. 123). Portanto, a verdade da indissolubilidade decorre do amor conjugal; e não o contrário!

Em sua teologia, "Scotus começa e termina com o Amor de Deus e com o Deus que é Amor. À luz disto, ele é certamente não só um verdadeiro filho de são Francisco, mas também 'o teólogo do Amor de Deus' na tradição franciscana” (MULHOLLAND, 1993, p. 249). Deus cria o mundo por amor e na plena liberdade, sem qualquer necessidade disso; e determina a Encarnação de seu Filho também exclusivamente por uma iniciativa amorosa e livre. O intelecto, a verdade e a necessidade da natureza decorrem da vontade primordial de Deus, que é amor em sua essência. Da mesma forma, não se há de buscar outra motivação para a celebração de um matrimônio que o amor livre e gratuito, não dependente de qualquer necessidade. Francisco cita diversas vezes as catequeses sobre a chamada "teologia do corpo", de João Paulo II, que rejeitou a ideia equivocada segundo a qual a doutrina da Igreja tolera o sexo humano "simplesmente 'pela necessidade da procriação"' ( $\mathrm{AL}, \mathrm{n}$. 150). Não é a necessidade da natureza que funda o sacramento do matrimônio, mas a contingência da vontade, isto é, a gratuidade do livre consentimento.

Enfim, se a vontade tem primazia sobre o intelecto, o produto da vontade a saber, a caridade - é mais nobre que o do intelecto - i.e., a verdade. Essa é uma contribuição importante que Scotus oferece aos teólogos do nosso tempo: o sentido da teologia, sua razão última de ser, não é especulativa ou contemplativa, mas sobretudo prática, caritativa. Essa noção, aplicada à pastoral familiar e particularmente aos casos especiais, é revolucionária. Não é à toa que tal abordagem tem recebido tantas críticas por parte de forças conservadoras do catolicismo: sendo a verdade da ordem do necessário e a caridade, da ordem do contingente, um apostolado junto às famílias à luz da AL dá muito mais trabalho, não tem respostas prontas e lança os pastores em missão muito mais desafiadora, devido à complexidade que a liberdade sempre traz consigo. 


\section{Siglas}

$\mathrm{AL} \quad=$ Amoris Laetitia

$\mathrm{CV}=$ Caritas in Veritate

$\mathrm{EG}=$ Evangelii Gaudium

Lec. = Lectura, de João Duns Scotus

Ord. = Ordinatio, de João Duns Scotus

S.c.G. = Suma contra os gentios

S.Th. = Suma Teológica

\section{Referências}

ALMEIDA, J. R. Amoris Laetitia em debate. Aparecida: Santuário, 2018.

ALMEIDA, J. R. Univocidade e diferença: a contribuição de Duns Scotus para uma Teologia Decolonial. 2020. Tese (Doutorado em Teologia) - Faculdade Jesuíta de Filosofia e Teologia, Belo Horizonte, 2020.

AUGUSTINUS. De Trinitate. In: S. Aurelii Augustini Opera Omnia. Patrologia Latina. Paris: J.-P. Migne, 1841. n. 42, p. 819-1098.

AUGUSTINUS. De correptione et gratia. In: S. Aurelii Augustini Opera Omnia. Patrologia Latina. Paris: J.-P. Migne, 1865. n. 44, p. 916-946.

BENTO XVI, Papa. Carta Encíclica Caritas in Veritate. 29 jun. 2009. Disponível em: http://www.vatican.va/content/benedict-xvi/pt/encyclicals/documents/hf_ben-xvi_enc_20090629_caritas-in-veritate.html. Acesso em: 02 nov. 2019.

BÍBLIA de Jerusalém. Nov.ed.rev. São Paulo: Paulus, 2002.

CEZAR, C. R. Introdução. In: SCOTUS, J. D. Scotus e a liberdade: textos escolhidos sobre a vontade, a felicidade e a lei natural. São Paulo: Loyola, 2010. (Humanística, 15).

CEZAR, C. R. Compreender Scotus. São Paulo: Loyola, 2014.

CÓDIGO de Direito Canônico. Tradução da Conferência Nacional dos Bispos do Brasil. São Paulo: Loyola, 1983.

COPLESTON, F. A history of philosophy. New York: Doubleday, 1993. v. 2.

CROSS, R. Duns Scotus. New York; Oxford: Oxford University Press, 1999.

FONTES Franciscanas e Clarianas. Petrópolis: Vozes, 2004.

FRANCISCO, Papa. Exortação Apostólica Evangelii Gaudium sobre o anúncio do evangelho no mundo atual. São Paulo: Paulinas, 2013.

FRANCISCO, Papa. Exortação apostólica pós-sinodal Amoris Laetitia sobre o amor na família. São Paulo: Paulinas, 2016.

INGHAM, M. B. Understanding John Duns Scotus: 'Of realty the rarest-veined unraveller'. St. Bonaventure: Franciscan Institute, 2017.

MULHOLLAND, S. Lo humano en la espiritualidad de Duns Escoto. Cuadernos Franciscanos, Santiago de Chile, v. 27, n. 104, p. 246-253, oct./dic. 1993. 
OROMÍ, M. Introducción general. In: Obras del Doctor Sutil: Dios uno y trino. Madrid: BAC, 1960.

PERRY, M. A. Una prospettiva francescana per un umanesimo cristiano rinnovato. Conferência na abertura do ano acadêmico 2017-2018 da Pontifícia Universidade Antonianum. Roma. 09 nov. 2017. Disponível em: http://www.scoto.net/index.php/ commis sione/archivio/44-atto-accademico-2017. Acesso em: 22 fev. 2018.

PRENTICE, R. The voluntarism of Duns Scotus, as seen in his comparison of the intellect and the will. Franciscan Studies, EUA, v. 28, 1968. p. 63-103.

SCOTUS, I. D. Reportatio Parisiensis. In: Opera Omnia. Paris: Ludovicum Vivès, 1894. v. 22-24.

SCOTUS, I. D. Lectura. In: Opera Omnia. Roma: Typis Polyglottis Vaticanae, 19602004. v. 16-21.

SCOTUS, I. D. Ordinatio. In: Opera Omnia. Roma: Typis Polyglottis Vaticanae, 1950-2013. v. 1-14.

SCOTUS, I. D. Textos sobre poder, conhecimento e contingência. Porto Alegre: EdiPUCRS; Editora Universitária São Francisco, 2008.

TAVARES, S. S. Teologia da criação: outro olhar - novas relações. Petrópolis: Vozes, 2010.

TODISCO, O. L'io-voglio come potenziale decostruttivo del totalitarismo: Hannah Arendt interprete di Duns Scoto. In: Il dono dell'essere: sentieri inesplorati del medioevo francescano. Padova: Messaggero, 2006. p. 365-422.

TODISCO, O. Libertar a verdade: a modernidade antimoderna de João Duns Scotus. Revista Eclesiástica Brasileira, Petrópolis, v. 272, p. 844-869, out. 2008.

TODISCO, O. Duns Scoto e Cartesio: ovvero la modernizzazione del pensare francescano. In: La libertà creativa: la modernità del pensare francescano. Padova: Messaggero, 2010.

TODISCO, O. Duns Scoto e il primato della volontà. In: Nella libertà la verità: lettura francescana della filosofia occidentale. Padova: Messaggero, 2014. p. 119-173.

TOMÁS, de A. Suma Teológica. São Paulo: Loyola, 2001-2006. 9 v.

TOMÁS, de A. Suma contra os Gentios. São Paulo: Loyola, 2015-2016. 4 v.

Artigo submetido em 26.12.2020 e aprovado em 05.04.2021.

Juliano Ribeiro Almeida, é Doutor em Teologia pela Faculdade Jesuíta de Filosofia e Teologia (FAJE - 2020) e Mestre em Teologia pela School of Theology and Ministry, do Boston College. É professor no Instituto Interdiocesano de Filosofia e Teologia, em Vitória-ES, e no Seminário propedêutico Bom Pastor, em Cachoeiro de Itapemirim - ES. Orcid.org/0000-00017491-2713. E-mail: julianorial@gmail.com

Endereço: R. Monsenhor João Batista Pavesi, n. 22 - Centro 29.500-000 Alegre - ES - Brasil 